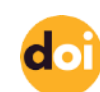

http://doi.org/10.22282/ojrs.2020.74

\title{
THE EARLY SPECIALIZATIONREN QUIRING SPORT OF GYMNASTICS AND LONG-TERM ATHLETE DEVELOPMENT PROGRAMS
}

\section{İsmail TEMÜRÇ $\dot{I}^{1}$, Işık BAYRAKTAR ${ }^{2}$, Özgür NALBANT ${ }^{2}$}

\begin{abstract}
${ }^{1}$ Alanya Alaaddin Keykubat University, Institute of Postgraduate Education, Department of Coaching Education
\end{abstract}

${ }^{2}$ Alanya Alaaddin Keykubat University, Sports Science Faculty, Department of Coaching Education

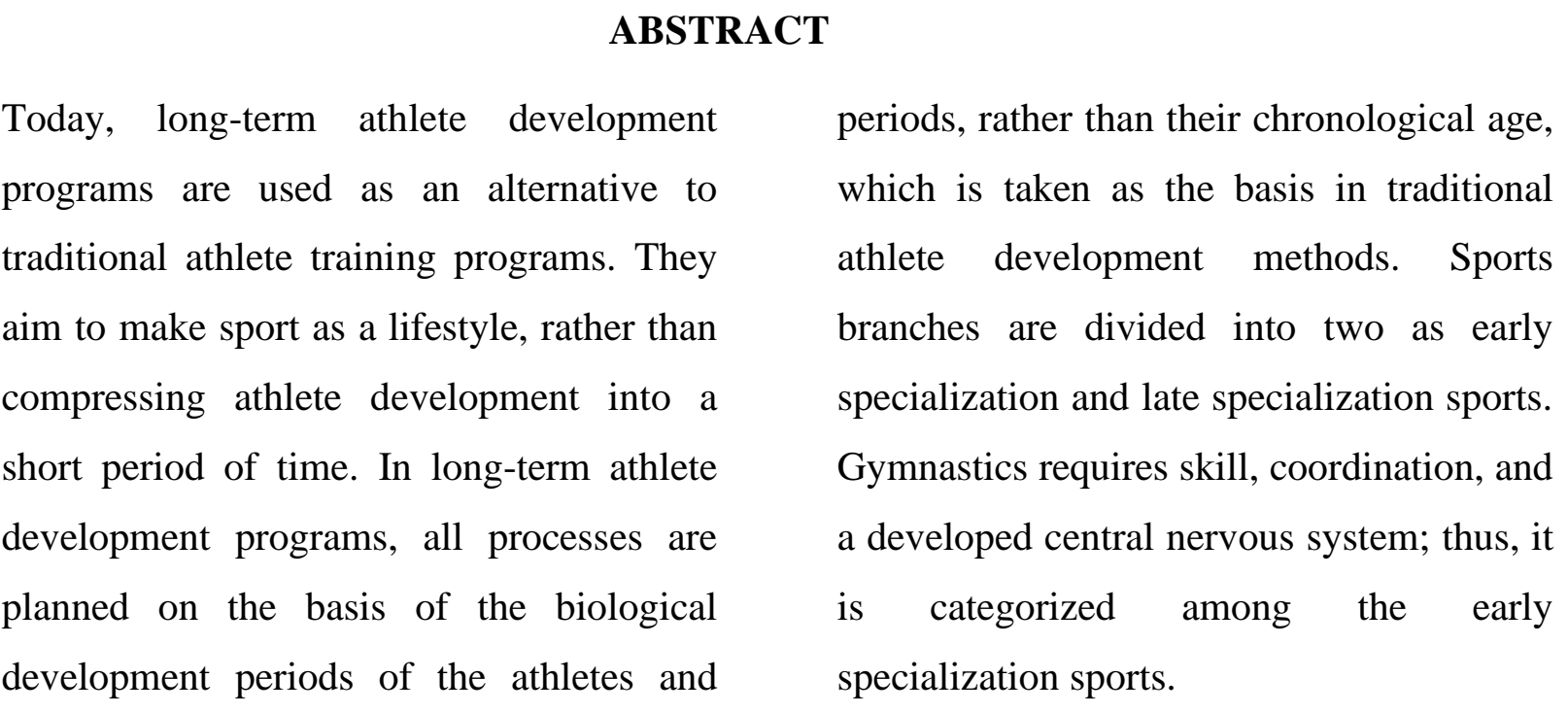

their development characteristics in these

Key Words: developmental age, early specialization, gymnastics, long-term athlete development, physical literacy 


\section{INTRODUCTION}

The term sports refers to all important activities that are created under a variety of branches and carried out in an organized and systematic way to ensure that individuals become physically, mentally, and psychologically healthy and a part of the society (Hazar, 2010).It is a well-known fact that starting sports at a young age has a significant impact on the positive relationships of individuals or societies and on raising children as citizens who have principles, believe in themselves and stay away from harmful habits (Koca, 2014).

Long-term athlete development (LTAD) is a sports approach that describes the formation of sports activities that are initiated in childhood within a planned, systematic and person-centered mannerin order to facilitateprofessional success in sports and ensure the engagement of individuals in physical activities to enhance their health throughout their lives (Balyi et al., 2016). A passive childhood is known to trigger a sedentary lifestyle later in adolescence and early adulthood. This is why it is necessary to regularly participate in strength and skill development activities from a very early age (Lloyd et al., 2015).

Scientists and coaches value the long-term development of young athletes. Training programs that are based and structured on the development of physical skills in childhood and adolescence to improve the success and performance of adult athletes is not a new understanding in sports training (Lloyd et al., 2015)

According to the performance components of sports branches, the question of "when to start specialization" is examined under the title of specialization in sports. LTAD models are also shaped according to this basic knowledge.

The purpose of this study was to examine the LTAD model in the field of gymnastics in all its dimensions and to present recommendations by discussing its applicability in Turkey. 


\section{Specialization}

In the LTAD model, sports branches are examined in two groups as early sport specialization and late sport specialization. Specialization refers to becoming an expert in any sport. While late specialization leads to positive outcomes in many sports branches, early specialization is notably important for a very limited number of sports branches to achieve significant results in both the national and international arenas (Balyi et al., 2016).

Biomotor abilities gain competence with the coordinated development of the central nervous system along with growth and maturation. These developmental stages are also the processes in which children's mobility-related abilitiesdevelop (Bağc1, 2009). The development of the central nervous system, which is crucial for creating conscious movements, begins in the womb and continues to develop gradually after birth (Suveren, 1998).

In the period from birth to the age of five the gross motor abilities are used, while in the period from the age of five to the age of nine, motor abilities that require small muscle control are used. Physical activity improves cognitive features as well as motoric properties. For maximum benefit, it is important that the cognitive process related to movement experiences is revealed by taking into account the developmental periods of children (Sevimay and Özer 2016). Research has shown that in order for the central nervous system to develop healthily before puberty, it is necessary to start multifaceted neuromuscular training at an early age (Lloyd et al., 2015).

To ensure early specialization, athletes should begin training in the sports they wish to master at a very young age and focus on that specific area (Granacher and Borde, 2017). Due to their basic characteristics, sports branches that prioritize high-level techniques and motor skills require early specialization as they are also connected to the central nervous system (Balyi and Hamilton, 2004).

In order to achieve success in acrobatics and artistic sports such as figure skating and gymnastics, it is necessary to train at an early age, namelybetween the ages of 5-7, in accordance with the characteristics of the sports event.Such sports events require a high level of complex movement and motor skills. These sport-specific abilities should be acquired by females before the age of 12 and by males before the age of 14 (Balyi et al., 2016). 
Professional sports experts recommend a certain age, namely12-15 years, to start specializing in sports such as boxing, canoeing, cycling and weightlifting. However, gymnastics and swimming are sports branches that require early specialization beginning from the ages of 6-9 years old (Balague, 2000). It is important for children to start sports that require early specialization in preschool-age to achieve a high level of efficiency in such branches in the future (Lloyd and Oliver, 2012).

In order to achieve a positive and effective performance level in every sport, it is necessary to create effective training loads (Lloyd and Oliver, 2012). However, overworking during the specialization process at an early age has been proven to have various negative effects such as injuries, overtraining, and withdrawal from sports (DiFiori et al., 2014).

Specialization in sports, which is a sensitive subject, is examined within the framework of growth and development principles in LTAD models.

\section{Growth and Development, Biological Maturity and Peak Height Velocity}

Growth can be expressed as an increase in the size and weight of a living being. Development, on the other hand, is the changes that occur in the body in an interactive and specific order as a result of internal and external influences and continue throughout a duration. There are individual differences in development. Everyone is known to have a unique form of development. As a result, although development is specific to the person, all individuals go through the same stages of development (Ersöz et al., 2012). Biological maturity is determined using skeletal age, gender development status and somatic maturity (Malina and Bouchard, 1992).

The LTAD model reveals that height and body weight measurements are routinely recorded in order to explain the peak height velocity (PHV) and peak weight velocity (PWV), which reflect maturation rates. PHV corresponds to the maximum growth rate of height and is used to describe the improvements in performance relative to the adolescent growth rate. PWV is a developmental period characterized by rapid muscle weight gain due to elevated concentrations of sex hormones (Ford et al., 2011). By objectively measuring the rates of 
change in height and body weight, it is emphasized that children can be trained based on biological age rather than chronological age (Balyi and Hamilton, 2004).

In athlete development models prior to the LTAD model, the chronological age of athletes was taken into account, while developmental age was not considered important (Balyi et al., 2016). The first steps taken to embody the LTAD model were based on studies that distinguished the development of elite athletes and revealed various levels of learning: the first, middle, and final years (Bayraktar, 2019). These initial trials for LTAD are considered erroneous, as they only take into account the chronological age (Vaeyens et al., 2008).

\section{Long Term Athlete Development and Gymnastics}

Gymnastics is among the early specialization sports as it requires high skill-demanding technical and motor abilities that depend on the nervous system (Açıkada and Hazır, 2016).

Developed by the Canadian Gymnastics Federation in 2009, the LTAD model is structured in eight stages according to the developmental age and individual characteristics of children (Sport for Life).

1) Active Start (Boys and Girls: 0-6 years)

Gymnastics is the starting activity for basic movement training. The activity level of gymnastics includes children in the pre-school age group. Participants are given the opportunity to progress at their own pace and work with a program that matches their characteristics. At this stage, which is child-centered, the physical environment should be organized in such a way that children can move comfortably (Sport For Life). In the stage of active participation, all children should be provided with movement training in order to create a dynamic and healthy society.The planned activities should support children's physical abilities as well as their cognitive features (Balyi et al., 2016).

2) Fun, Fitness and Basic Movement Patterns (Boys: 6-9 years, Girls: 6-8 years)

This is the period in which gym-specific skills are developed through fun activities and games. At this stage, participants will master basic movement patterns and begin to learn 
gymnastic skills (Sport for Life). It can be a stage of opportunity for participants. Children should not be pressured but allowed to have fun and have a pleasant time (Balyi et al., 2016).

3) Developing Gymnastics Skills (Boys: 9-10 years, Girls: 7-9 years)

The content of the sports practices should be prepared according to the skill and fitness levels of the children. At this stage, participants continue to develop their gymnastics and general sports skills. Focus is placed on features including agility, balance, coordination and flexibility (Sport for Life). The acquired gymnastics experience will make it easier for those who want to move on to other branches and those who want to become advanced athletes. Children should test all of the activities of the sport they are interested in (Balyi et al., 2016).

4) Specializing in a Sport Branch (Boys: 10-12 years, Girls: 9-11 years)

This stage involves teaching children complex gymnastic skills. At this stage, in which motor skill development is most important, physical preparation and cognitive development are provided. A rapid adaptation process occurs in this stage. At this age, those who continue to practice gymnastics begin to enjoy it and take an important step towards specialization in gymnastics. However, it is necessary to take an initiative for the possibility of transition to other sports (Sport for Life). Solid basic skills must be built and the foundations of a long-term commitment to the sport must be laid. Having fun still retains its importance at this stage. As the training stages progress, the concept of fun takes on a different meaning (Balyi et al., 2016).

5) Being a Consistent Competitor (Boys: 12-15 + years, Girls 10-13 + years)

Athletes who reach this stage posses a competitive attitude towards a specific goal. They enjoy competing at national and international levels (Sport For Life), devote themselves exclusively to gymnastics and try to set a standard for being professional. These athletes are in close contact with their coaches (Balyi et al., 2016). This is the stage of puberty for almost all men and women. Coaches should pay attention to the PHV and PWV of the athletes, and carefully track growth (Sport for Life). More emphasis should be placed on emotional and social issues. Passing this stage properly can enable athletes to become international level competitors (Balyi et al., 2016). 


\section{6) Win at Each Level (Boys: 15-18 + years, Girls: 13-18 + years)}

The primary determinant of success is the ability to perform an exercise of high difficulty with a high execution score (Agopyan and Ors, 2019). Gymnasts at this stage optimize their performance according to the goals they set for themselves. Athletes at this level perform well and are focused on results. Those who are aware of what they are doing act independently, and cooperate with their coaches in setting goals and making decisions (Sport For Life). Annual plans are also included in this stage. In order for these plans to have functional and effective results, the life of the athlete outside of training and competitions is also planned out (Balyi et al., 2016).

7) International Excellence and Podium Performances (Boys: 18+ years, Girls: $16+$ years)

Gymnasts at this stage are at their highest level. They represent their country in international competitions and take part as competitors in major organizations in their country. They are invited to world championships and the most prestigious international events (Sport For Life). Gymnasts at this stage are expert athletes and now work for the Olympic stage (Balyi et al., 2016).

8) Lifelong Gymnastics (boys and girls of all ages)

This stage encourages individuals to remain physically active for life, whether at a competitive or recreational level. At this stage, there are gymnastic activities of all levels (Sport For Life).This stage is a lifestyle that requires physical mobility, which is the key to a healthy life for people of all ages whether they are Olympic athletes or sedentary (Balyi et al., 2016). This is the period when elite athletes begin to withdraw from Olympic-level competitions (Sport for Life).

\section{LTAD Gymnastics and Canada}

The LTAD model has been systematically implemented in gymnastics by the Canadian Gymnastics Federation since 2005. The model presents a draft that strengthens and enhances the gymnastics division, in line with the priorities set by the Canadian National Olympic Committee. 
These programs allow children to have fun and do the activities they want. Three categories, namely the bronze, silver and gold categories, have been determined to develop their skills. These categories were created to form a friendly and encouraging environment for all participants and coincide with Canada's educational philosophy (Sport for Life).

\section{CONCLUSION}

In this study, the branch of gymnastics, which requires specialization at an early age, was examined from the perspective of the LTAD model, which evaluates sports from a longitudinal point of view.

The LTAD model, which is implemented in Canada, allows gymnasts to progress systematically and engage in sports throughout their lives, as it is both child-and athletecentered. This model covers all stages from the initial stage and non-competitive participants to the stage of becoming elite athletes. The fact that athletes have different ages, different physical characteristics and mental maturity is taken into account. Thus, the criteria given for each stage are arranged according to students' characteristics and individual differences.

It is believed that examples of applications that reflect the understanding of the LTAD model in gymnastics will increase in the future as more researchers focus on this topic, and thus LTAD models will become widespread in different countries.

\section{REFERENCES}

Açıkada, C., ve Hazır, T. (2016). Uzun Süreli Sporcu Gelişim Programları: Hangi Bilimsel Temellere Oturuyor? Spor Bilimleri Dergisi Hacettepe Üniversitesi, 27(2), 84-99. https://doi.org/10.17644/sbd.255156

Agopyan, A., \& Örs, B. S. (2019). An analysis of variations in body movement difficulty of 2016 Olympic Games rhythmic gymnast candidates. International Journal of Performance Analysis in Sport, 19(3), 417-434.

Bağc1, E. (2009). 10 - 12 Yaş grubu aerobik cimnastik branşı ile uğraşan yarışmacı bayan sporcular ile ayn yaş grubu sedanter öğrencilerin bazı fiziksel özelliklerinin eurofit test bataryası ile karşılaştırılması. Gazi Üniversitesi Sağlık Bilimleri Enstitüsü Beden Eğitimi ve Spor Anabilim Dalı, Ankara, Türkiye. 
Balague, G. (2000). Periodization of pyschological skills training. Journal of Science and Medicine in Sport, 3(3), 230-237.

Balyi, I., Hamilton, A. (2004). Long-Term Athlete Development: Trainability in Childhood and Adolescence. Olympic Coach, 16(1), 4-9.

Balyi, I., Way, R. ve Higgs, C. (2016). Uzun Vadeli Sporcu Gelişimi (Çev. E. Pekünlü, İ. $\ddot{O} z s u)$. Ankara: Spor Yayınevi ve Kitabevi.

Bayraktar, I. (2019). Geleneksel Yetenek Seçimi mi, Uzun Dönem Sporcu Gelişimi mi? Içinde G. Hergüner (Ed.), Her Yönüyle Spor (ss. 10-31). İstanbul: Güven Plus Grup.

DiFiori, J. P., Benjamin, H. J., Brenner, J. S., Gregory, A., Jayanthi, N., Landry, G. L., Luke, A. (2014). Overuse injuries and burnout in youth sports: a position statement from the American Medical Society for Sports Medicine. British journal of sports medicine, 48(4), 287-288.

Ersöz, Y. (2012). Çoklu beceri spor eğitim programının 7-10 yaş grubu erkek çocuklarda motor gelişime etkisi. Dokuz Eylül Üniversitesi Sağlık Bilimleri Enstitüsü, Spor Fizyoljisi Yüksek Lisans Tezi, İzmir, Türkiye.

Ford, P., De Ste Croix, M., Lloyd, R., Meyers, R., Moosavi, M., Oliver, J., Williams, C. (2011). The long-term athlete development model: Physiological evidence and application. Journal of sports sciences, 29(4), 389-402.

Granacher, U., \& Borde, R. (2017). Effects of sport-specific training during the early stages of long-term athlete development on physical fitness, body composition, cognitive, and academic performances. Frontiers in Physiology, 8(10), 1-11. https://doi.org/10.3389/fphys.2017.00810

Hazar, Z. S. İ. (2010). Amatör futbol takımında müsabaka dönemi antrenmanının performans parametrelerine tkisi. Selçuk Üniversitesi Beden Eğitimi ve Spor Bilimleri Dergisi,12(3), 12(3), 239-243. 2.

Koca, B. (2014). Cimnastik, yüzme ve atletizm branşlarında yarışmalara kattlan 12 yaş çocukların motor özelliklerinin karşslaş̧tırlması. T.C. Haliç Üniversitesi Sağlık Bilimleri Enstitüsü Beden Eğitimi ve Spor Anabilim Dalı, İstanbul, Türkiye.

Lloyd, R. S, Oliver, J. (2012). The youth physical development model: a new approach to long- 
term athletic development. Strength and Conditioning Journal, 34(3), 61-72. https://doi.org/10.1519/SSC.0b013e31825760ea

Lloyd, R. S., Oliver, J. L., Faigenbaum, A. D., Howard, R., De Ste Croix, M. B. A., Williams, C. A., Best, T. M., Alvar, B. A., Micheli, L. J., \& Myer, G. D. (2015). Long-term athletic development, Part 2: Barriers to success and potential solutions.. Journal of Strength and Conditioning Research.29(5), 1451-1464.

Malina, R. M., Bouchard, C. (1992). Growth, Maturation, and Physical Activity.Human Kinetice, illinoisMedicine \& Science in Sports \& Exercise. https://doi.org/10.1249/00005768-199207000-00018

Sevimay, D., Özer, K. (2016). Çocuklarda Motor Gelişim. (N. Argun (ed.)). Ankara: Nobel Akademik Yayıncılık Eğitim Danışmanlık.

Sport For Life(2020). LTAD-Quality Sport Programs.Erişimtarihi: 18 mayı 2020 http://sportforlife.ca/resources/quality-sport-programs/

Suveren, S. (1998). 6-7 Yaş grubu cimnastiğe yeni başlayan erkek çocuklarda atlama beygiri aletinde uberschlag hareketinin ögretilmesinde sözel eğitim ve video kamera ile eğitim yöntemlerinin karşılaş̧tırllması. Gazi Üniversitesi Sağlık Bilimleri Enstitüsü Beden Eğitimi ve Spor Anabilim Dalı. Ankara, Türkiye.

Vaeyens, R., Lenoir, M., Williams, A. M., \& Philippaerts, R. M. (2008). Talent identification and development programmes in sport: current models and future directions. Sports Medicine, 38(9), 12. https://doi.org/10.2165/00007256-200838090-00001 